\title{
EL TRATAMIENTO DEL INIMPUTABLE ENAJENADO MENTAL EN EL PROCESO PENAL CHILENO
}

\author{
Centro de Estudios de la Justicia *
}

\begin{abstract}
I. Introducción. La inimputabilidad por enajenación mental y las garantias jurídicas sustanciales y procesales; II. Situación general del imputado enajenado mental en el Código Procesal Penal; III. Adjudicación de las medidas de seguridad; IV. Breves consideraciones acerca de la ejecución de las medidas de seguridad; $V$. Reglas particulares para el sujeto que cae en enajenación mental durante el procedimiento.
\end{abstract}

\section{Introducción. La inimputabilidad por enajenación mental y las garantías jurídicas sustanciales y procesales}

La Defensoría Penal Pública ha encargado al Centro de Estudios de la Justicia de la Facultad de Derecho de la Universidad de Chile la realización de un informe en Derecho sobre la posición jurídica del enajenado mental en el proceso penal chileno. Esta temática no sólo ha sido objeto de una escasa preocupación por parte de la doctrina nacional: tampoco ha sido objeto de debate en el ámbito político y, en general, público. Sólo con la dictación, primero, del Código Procesal Penal que modificó radicalmente el tratamiento procesal punitivo de los enfermos mentales a quienes se les atribuye la comisión de un delito y, posteriormente, con la nueva ley de responsabilidad penal del adolescente ${ }^{1}$ se ha abordado de modo general la cuestión acerca de cuál es la respuesta penal más adecuada para aquellos sujetos que tradicionalmente han sido considerados inimputables desde el punto de vista jurídico-penal y cuáles son los presupuestos y límites, tanto materiales como procesales, para que puedan ser sujetos pasivos de alguna forma de intervención punitiva.

Tradicionalmente la imputabilidad y, más concretamente, su aspecto negativo, la inimputabilidad ha sido vista como un problema en torno a la articulación del juicio de reprochabilidad ${ }^{2}$, esto es, con el conjunto de facultades

\footnotetext{
* Este artículo corresponde a un informe en derecho encargado por la Defensoría Penal Pública y fue elaborado por la Directora del Centro de Estudios de la Justicia, Dro. María Inés Horvitz Lennon, con la colaboración de los investigadores Jonatan Valenzuela Saldías y Luppy Aguirre Bravo. El Centro de Estudios de la Justicia agradece a la Defensoría Penal Pública la autorización concedida para su publicación.

${ }^{1}$ Cfr. Ley 20.084, sobre responsabilidad penal del adolescente, cuya vigencia fue postergada hasta el mes de junio del año 2007.

2 Ver por todos Roxin, Claus, Derecho Penal, Parte General, Civitas, 1997, traducción de Diego Manuel Luzón Peña, Miguel Díaz y García Conlledo y Javier de Vicente Remesal, página 42, en lo siguientes términos: "[...] toda pena presupone culpabilidad del sujeto cuando cometió un hecho
} 
mínimas requeridas para considerar a un sujeto culpable por haber cometido un hecho típico y antijurídico. Este concepto ha sido analizado desde los diferentes paradigmas -médico, psicológico, sociológico- que han tenido una fuerte influencia en su definición jurídico-penal. Tanto el planteamiento clásico ${ }^{3}$ como el positivismo naturalista ${ }^{4}$, a pesar de sus radicales diferencias, han dejado su huella en la evolución del mismo. En efecto, el concepto de "peligrosidad" acuñado por el positivismo criminológico no logró desplazar completamente, como en principio se pretendía, la doctrina clásica de la imputabilidad basada en la libertad, pero sí ha conseguido, en cambio, convivir "pacíficamente" con ella ${ }^{5}$. Esta circunstancia se manifiesta claramente en los binomios culpabilidad-pena y peligrosidad-medida de seguridad en que se divide el tratamiento de los imputables-inimputables y que se hace particularmente crítico en las legislaciones que admiten el sistema dualista de sanciones ${ }^{6}$.

El concepto de imputabilidad dependerá siempre del concepto de culpabilidad al que se adhiera. Todavía hoy es posible afirmar que predomina aquél que se sustenta en las ideas de capacidad de comprensión de las normas (motivabilidad normativa normal) y de autodeterminación conforme a esa comprensión ${ }^{7}$. Desde esta perspectiva, dominante en la doctrina nacional ${ }^{8}$, la

en el pasado, y en cambio toda medida de seguridad presupone una continuada peligrosidad del sujeto para el futuro [...]"

3 Abarcando dentro de él a todas aquellas corrientes de pensamiento que, partiendo de una consideración dogmática del delito, esto es, como ente jurídico, fundan la responsabilidad penal (en el sentido de contestar por el delito cometido) en la libertad humana, más precisamente, en la voluntad libre (vid. por todos, Sotomayor, J.O.: Inimputabilidad y sistema penal, Temis, 1996, pp. 31 y ss.)

${ }^{4}$ En esta corriente resulta paradigmática la Escuela Positiva italiana (Lombroso, Garofalo, Ferri) y su impacto en las teorías de la defensa social. Hoy pervive en la noción psicologizante o psiquiátrica de culpabilidad que, aunque se normativizó en los sucesivos desarrollos dogmáticos, sólo ha perdido esta dimensión original individual en los postulados del funcionalismo normativista radical y en algunos planteamientos sociológicos particulares que ponen énfasis en el componente social, colectivo de la responsabilidad penal (cfr. Sotomayor, J.O., cit., passim). Especialmente interesante es la posición de Kindhäuser, quien siguiendo a Habermas, configura un concepto de culpabilidad material basado en la idea de autonomía comunicativa, en que se puede afirmar que el sujeto debió motivarse por la norma si concretamente goza de la más plena vigencia de sus derechos tanto en la esfera pública como privada, que hace materialmente posible que haga valer sus puntos de vista en el proceso discursivo (comunicación orientada al entendimiento) de creación de las normas, y que el resultado de ese proceso exprese una visión de bien común (cfr. Derecho penal de la culpabilidady conducta peligrosa (trad. de Claudia López Díaz), U. Externado de Colombia, 1996, pp. 33 y ss.; también, "La fidelidad al derecho como categoría de la culpabilidad" (trad. Percy García C.) en: Luzón Peña y otros (dirs.) Cuestiones actuales de la teoría del delito, Madrid, 1999, pp. 185 y ss.

${ }^{5}$ Díaz Palos, Fernando, Teoría general de la inimputabilidad, Barcelona, Bosch, 1965.

${ }^{6} \mathrm{Al}$ respecto, cfr. Muñoz Conde, Francisco: "Penas y medidas de seguridad: monismo versus dualismo", en el mismo, Derecho Penal y control social, Jerez, 1985, pp. 51 y ss;

7 Aunque las críticas surgidas a partir de la indemostrabilidad, a lo menos dentro de los límites heurísticos del proceso penal, de la libertad de actuación han llevado a una crisis del concepto clásico de culpabilidad y a su revisión crítica como fundamento material de la imposición de la pena, pero no en cuanto a su utilidad como límite de la pena. 
imputabilidad decae cuando, por la fase vital de desarrollo en que se encuentra, sus características psíquicas o su estado de conciencia, el sujeto no es capaz de comprender los mensajes normativos y, por consiguiente, no es motivable por ellas. No obstante, este entendimiento puramente individual de la imputabilidad olvida los problemas de accesibilidad normativa de aquellos que experimentan situaciones de marginalidad social o que, lisa y llanamente, no participan de la racionalidad hegemónica del Estado expresada en un determinado orden jurídico, sino de una racionalidad alternativa y legítima en una sociedad pluralista. Este planteamiento, todavía minoritario en la doctrina ${ }^{9}$, postula que la colectividad no puede "exigir" al individuo motivarse por las normas (modelo de inimputabilidad basado en la idea de inexigibilidad), existiendo incluso corresponsabilidad del Estado si no se proporcionaron los medios al sujeto para participar en los bienes sociales y en la internalización (comunicativa) de los valores hegemónicos. Ya se trate de una cuestión de inaccesibilidad a la motivación normativa o de inexigibilidad en el cumplimiento de las normas, el instrumento penal sería percibido en estos casos por la colectividad como innecesario y abusivo, esto es, carente de toda necesidad preventivo-general ${ }^{10}$. En otras palabras, respecto de los inimputables no cabe esperar que se cumplan las expectativas de conducta contenidas en las normas penales, confirmando así la necesidad de su cumplimiento por las demás personas que no se encuentran en dicha situación.

Las afirmaciones precedentes no afectan, sin embargo, otras funciones del derecho penal que aún hoy se consideran legítimas en este ámbito, como es la prevención de la peligrosidad del enajenado mental que se exterioriza en la comisión de hechos punibles y se pretende realizar a través de medidas de seguridad. Esta solución, acogida en la legislación penal chilena como en la mayoría de los ordenamientos jurídicos de nuestro ámbito cultural, es clara manifestación de un compromiso entre el derecho penal clásico del siglo XIX y la Escuela Positiva ${ }^{11}$. La situación descrita ha significado que, en el sistema penal

${ }^{8}$ Cfr. Etcheberry, Alfredo, Derecho Penal, Parte General, Tomo I, Editorial Jurídica de Chile, $3^{\text {a }}$ edición, 1997, pp. 278 y siguientes; Politoff, Sergio, Derecho Penal, Tomo I, Editorial Conosur, 1997, pp. 526 y siguientes; Garrido Montt, Mario, Derecho Penal, Parte General, Tomo II, Editorial Jurídica de Chile, $3^{\mathrm{a}}$ edición, 2003, pp. 205 y siguientes, Couso, Jaime, Fundamentos del derecho penal de culpabilidad, Tirant Lo Blanch, Valencia, 2006, en especial pp. 153 y siguientes; Politoff/Matus/Ramírez, Lecciones de derecho penal chileno, Editorial Jurídica de Chile, 2003, pp. 294 y siguientes; Künsemüller, Carlos, Culpabilidad y pena, Editorial Jurídica de Chile, 2001, pp. 180 y siguientes.

${ }^{9}$ Cfr. Bustos, Juan: Manual de derecho penal. $4^{\mathrm{a}}$ ed. aumentada, corregida y puesta al día por Hernán Hormazábal M., Ariel, Barcelona, 1994, pp. 519 y ss. También, Couso, cit., pp. 446 y ss.

10 En este sentido, entre otros, Gimbernat Ordeig, E., "El sistema del derecho penal en la actualidad", en Estudios de Derecho Penal, Madrid, Tecnos, $3^{\text {a }}$ ed., 1990, pp. 175 y ss.; Mir Puig, S., El derecho penal en el estado social y democrático de derecho, Barcelona, Ariel, 1994, pp. 80 y ss. Me parece, además, que este planteamiento permite tomar en consideración la relación entre autor y norma como condición de legitimidad para la exigibilidad de las conductas (sobre la dimensión social, dialéctica del concepto de culpabilidad. Cfr. Muñoz Conde, F., Derecho Penal (PG), $5^{\text {a }}$ ed., 2002 , pp. 360 y ss.

${ }^{11}$ Vid. supra nota 4. 
paralelo que ha regido para los sujetos declarados inimputables, no existan más garantías ni un tratamiento punitivo más benigno que el de los imputables - en razón de su déficit motivacional-, sino que, por el contrario, tengan vigencia preferente los postulados del positivismo criminológico ${ }^{12}$. La "anormalidad psíquica" del sujeto sería sintomática de su personalidad peligrosa y, de este modo, se impondría la aplicación de una medida de seguridad con contenido terapéutico sin necesidad que aquél cometa un delito; de allí el planteamiento de las medidas de seguridad predelictuales ${ }^{13}$. La ideología del tratamiento (médico) ha legitimado la intervención ilimitada sobre el enfermo mental, fundamentalmente a través del encierro manicomial o internamiento, afectándose seriamente la dimensión garantista limitadora de la intervención punitiva estatal.

Como es sabido, y fruto de la ideología a que nos hemos referido, la situación jurídica del enajenado mental a quien se le imputaba la comisión de un delito era -hasta la reforma procesal penal- de total desprotección: bastaba que al sujeto se le declarara inimputable en el procedimiento penal para que pudiera aplicársele sin más una medida de seguridad, esto es, sin necesidad de establecer su participación en el delito imputado. La supuesta naturaleza "terapéutica", "curativa" o "tutelar" de dichas medidas, condujo a considerar que no eran necesarias las garantías jurídicas en su imposición, tanto sustantivas como procesales. Al igual que ha ocurrido con las medidas "educativas" o "tutelares" de los menores de edad ${ }^{14}$, este tipo de razonamiento ha encubierto el carácter sancionatorio en razón de un injusto -y no, por consiguiente, de "beneficencia"de las medidas de seguridad y que, por tanto, necesariamente su imposición ha de estar sujeta a todas las garantías propias de la intervención punitiva en un Estado de Derecho.

Sin embargo, sólo a partir de 2000 se ha diseñado legalmente un procedimiento con todas las garantías del debido proceso para el enajenado mental a quien se atribuye la comisión de un delito y respecto de quien se solicita la aplicación de una medida de seguridad. Tal decisión político-legislativa estuvo directamente vinculada con la impronta garantista del nuevo sistema procesal penal y con los modelos y antecedentes legislativos de derecho comparado tenidos a la vista que imponían una reforma radical en este ámbito.

En este sentido, el Mensaje del nuevo Código Procesal Penal expresa:

\footnotetext{
12 Cfr. Baratta, Alessandro, Criminología y sistema penal, editado por B de F, Buenos Aires, 2004, en especial páginas 89 y ss. También: Anitua, Gabriel I., Historias de los pensamientos criminológicos (prólogo de E.R. Zaffaroni), Del Puerto, Buenos Aires, 2005, pp. 179 y ss.

13 Manifestación de ellas, en nuestro sistema jurídico, fueron las medidas establecidas por la Ley 11.625, sobre Estados Antisociales, de 10 de abril de 1954, las que, sin embargo, no pudieron operar por problemas económicos e infraestructurales.

${ }^{14}$ Sobre las consecuencias de la ideología tutelar en el tratamiento penal de los menores, vid., por todos, Cillero, Miguel/Bernales, Martín: "Derechos humanos de la infancia/adolescencia en la justicia "penal de Menores" de Chile: evaluación y perspectivas" en Couso, Jaime (Dir.) Revista de Derechos del Niño, No 1, 2002, pp. 9 y ss.
} 
[e]ntre las innovaciones que vale la pena resaltar se encuentran la incorporación de garantias básicas en el procedimiento aplicable a los inimputables por enajenación mental. Entre estas garantias se encuentran las de limitar las posibilidades de aplicación de una medida de seguridad a aquellos casos en que se acredite judicialmente la existencia de un hecho típico y antijurídico, el reconocimiento del derecho a defensa del afectado, la limitación de la duración de la medida aplicable al tiempo correspondiente a la pena minima asignada al delito de que se trate y el establecimiento del control judicial de las medidas de seguridad.

Por consiguiente, el presente trabajo se centra en el tratamiento procesal penal del imputado enajenado mental, esto es, "el loco o demente" y el que "por cualquier causa independiente de su voluntad se halla privado totalmente de razón" (art. $10 \mathrm{~N}^{\circ} 1$ del Código Penal); por consiguiente, no se aborda la problemática del menor de 14 años $^{15}$. Tampoco nos referiremos al presupuesto material que da origen a la existencia de estas reglas procesales especiales, esto es, a la determinación de qué es una enfermedad mental y cuáles son sus diversas manifestaciones, pues ello corresponde por completo al derecho penal material y a los desarrollos de las disciplinas psiquiátricas ${ }^{16}$. Por consiguiente, nuestro objetivo es efectuar una interpretación sistemática y consistente de las normas que regulan el procedimiento aplicable al enajenado mental a quien se le imputa la comisión de un delito, como también de las medidas de seguridad que pueden aplicársele y su ejecución. Para ello, se ha tenido en consideración el profundo cambio cultural que ha significado el paso de un sistema jurídico de ausencia total de garantías a otro que reconoce la calidad de personas y de ciudadanos a los enfermos mentales, reforzándose su estatus jurídico cuando se trata de la imputación de un delito y/o la afectación de derechos individuales.

\footnotetext{
15 Único sujeto que puede ser considerado inimputable por minoría de edad a partir de la vigencia de la Ley 20.084.

16 Sobre las enfermedades mentales y las formas de su recepción en el derecho penal, cgr. Torío López, Angel, "Las fórmulas legislativas sobre la enfermedad mental. Discusión del concepto de enajenación”, en AA.VV: Estudios jurídicos en honor del profesor Octavio Pérez-Vitoria, T.II, Barcelona, Bosch, 1983; desde el punto de vista de la antisiquiatría, vid. Szasz, Thomas, "¿A quién sirve la psiquiatría?”, en Basaglia/Basaglia Ongaro (comp.): Los crímenes de paz (trad. de J.D. Castillo), México, Siglo XXI, 1981.
} 
CEJ - El tratamiento del inimputable en el derecho procesal penal chileno

\title{
II. Situación general del imputado enajenado mental en el Código Procesal Penal
}

\section{II.1 Presupuestos para la aplicación del procedimiento especial previsto en el Título VII del Libro IV del CPP}

El CPP chileno se ocupa del inimputable en las reglas contenidas en el Título VII del Libro IV, titulado "Procedimiento para la aplicación exclusiva de medidas de seguridad", que abarca los artículos 455 a 465.

En su artículo 458 (párrafo $2^{\circ}$ del Título VII del Libro IV), el CPP plantea el presupuesto necesario para la aplicación de un procedimiento especial determinado por las especiales características del sujeto imputado de delito:

\begin{abstract}
Art. 458. Imputado enajenado mental. Cuando en el curso del procedimiento aparecieren antecedentes que permitieren presumir la inimputabilidad por enajenación mental del imputado, el ministerio público o juez de garantía, de oficio o a petición de parte, solicitará el informe psiquiátrico correspondiente, explicitando la conducta punible que se investiga en relación a éste. El juez. ordenará la suspensión del procedimiento hasta tanto no se remitiere el informe requerido, sin perjuicio de continuarse respecto de los demás coimputados, si los bubiere.
\end{abstract}

Como puede apreciarse, la norma discurre sobre la base del tratamiento general de cualquier imputado como imputable, esto es, como sujeto capaz de culpabilidad y, por ende, de responder con la pena por el hecho cometido. La sospecha de enajenación mental del imputado impone la realización de ciertas actuaciones orientadas a confirmar o descartar la sospecha; pero si ella es confirmada corresponde la aplicación de un procedimiento especial que asegure de modo reforzado el ejercicio de los derechos y garantías vinculados al debido proceso a quien adolece de ciertas capacidades cognitivas o intelectuales para defenderse adecuadamente de una imputación penal.

Debe destacarse, sin embargo, que el procedimiento previsto en el Título VII del Libro IV del CPP no se aplicará necesariamente a todo inculpado inimputable por enajenación mental o trastorno mental transitorio, pues tal calidad constituye sólo uno de sus presupuestos. En efecto, la ley exige:

a) que se trate de un sujeto que sea declarado inimputable por el tribunal, por encontrase en alguno de los supuestos de hecho contemplados en el artículo $10 \mathrm{~N}^{\mathrm{o}} 1$ del Código Penal;

b) que dicho sujeto haya sido imputado de la comisión de un hecho típico y antijurídico; $y$

c) que existan antecedentes calificados que permitan presumir que atentará contra sí mismo o contra otras personas, de tal forma que se haga necesaria la aplicación de una medida de seguridad. 
Si durante el procedimiento se estableciere que el sujeto no cometió el delito que se le atribuye o concurre a su respecto cualquiera de las causales que eximen o extinguen la responsabilidad penal distinta de la prevista en el art. $10 \mathrm{~N}^{\circ}$ 1 del Código Penal, el ministerio público deberá solicitar el sobreseimiento definitivo conforme a las reglas generales. Si tales circunstancias se establecen en el respectivo juicio oral, el tribunal deberá absolver al imputado aunque existan antecedentes calificados que permitan presumir que atentará contra sí mismo o contra otras personas, pues el presupuesto de aplicación de la medida de seguridad es la comisión de un delito y no la mera peligrosidad del sujeto.

Los fundamentos legales de las conclusiones precedentes son los arts. 455, 460 inciso $1^{\circ}, 462$ inciso $1^{\circ}$ y 463 letra c) del CPP, cuyas disposiciones se transcriben a continuación:

Art. 455. Procedencia de la aplicación de medidas de seguridad. En el proceso penal sólo podrá aplicarse una medida de seguridad al enajenado mental que bubiere realizado un becho típico y antijuridico y siempre que existieren antecedentes calificados que permitieren presumir que atentará contra sí mismo o contra otras personas.

Art. 460. Actuación del ministerio público. Si el fiscal hallare mérito para sobreseer temporal o definitivamente la causa, efectuará la solicitud respectiva en la oportunidad señalada en el artículo 248, caso en el cual procederá de acuerdo a las reglas generales (...).

Art. 462. Resolución del requerimiento. Formulado el requerimiento, corresponderá al juez de garantía declarar que el sujeto requerido se encuentra en la situación prevista en el artículo $10 \mathrm{~N}^{o}$ 1, del Código penal. Si el juez. apreciare que los antecedentes no permiten establecer con certeza la inimputabilidad, rechazará el requerimiento (...) (y se continuará el procedimiento conforme a las reglas generales del procedimiento ordinario).

Art. 463. Reglas especiales relativas a la aplicación de medidas de seguridad. Cuando se proceda en conformidad a las normas de este Párrafo, se aplicarán las siguientes reglas especiales:

(...) c) La sentencia absolverá si no se constatare la existencia de un hecho típico y antijuridico o la participación del imputado en él, o, en caso contrario, podrá imponer al inimputable una medida de seguridad.

Nos parece importante destacar desde ya que el procedimiento previsto en el Título VII del Libro IV del CPP es aplicable tanto al sujeto que era inimputable al momento de cometer el delito (hipótesis del art. $10 \mathrm{~N}^{\circ} 1$ del Código Penal) como aquel que cae en enajenación mental después de iniciado el procedimiento y respecto de quien se hubiere formalizado la investigación o deducido acusación en su contra, si se estima -además- que corresponde aplicar una medida de seguridad 
CEJ - El tratamiento del inimputable en el derecho procesal penal chileno

por existir un pronóstico de que podría atentar contra sí mismo o contra terceros (art. $465 \mathrm{CPP}$ ). Esto es, también es aplicable este procedimiento especial a quien era imputable al momento de cometer el delito pero que deja de serlo durante el proceso penal que se inicie en su contra y sea considerado peligroso: la pena deja de ser útil preventivo-generalmente y pierde significación retributiva para el infractor; sólo cabría, por consiguiente, una función preventivo-especial a través de la imposición de una medida de seguridad.

II.2. Actuaciones previas a la aplicación del procedimiento especial previsto en el Título VII del Libro IV del CPP

\section{II.2.1. Sospecha de enajenación mental y situaciones procesales en que ella puede darse}

Existiendo antecedentes que permitan presumir la inimputabilidad por enajenación mental del imputado, el ministerio público podrá solicitar al juez de garantía -quien también podría decretarla de oficio- que se emita, por quien corresponda, un informe psiquiátrico del imputado, solicitud que debe indicar la conducta punible que se investiga y que se le atribuye.

Estos antecedentes pueden ser de toda clase, porque la ley no los limita. Así, podría contarse con informes médicos que indiquen la existencia de una enfermedad mental o, sencillamente, advertirse un comportamiento extraño en el imputado como, por ejemplo, respuestas incoherentes o absurdas a preguntas formuladas tanto por el ministerio público como por el juez de garantía en entrevistas personales o en audiencias.

Como se señaló, hasta este momento sólo se cuenta con la sospecha de existencia de uno de los presupuestos de aplicación de este procedimiento especial. Podría ocurrir que a la propia defensa interesara la comprobación del estado mental del imputado, ya para promover la aplicación de este procedimiento o ya para oponerse a él. La circunstancia de que el art. 458 CPP no se refiera expresamente a este interviniente no impide, en absoluto, su participación en este contexto, pues se trata de una manifestación fundamental del derecho de defensa material y técnica de todo imputado, cual es intervenir en la definición de las reglas que resultan más convenientes para el ejercicio de las garantías del debido proceso conforme a su condición personal.

A continuación nos pondremos en diferentes supuestos de sospecha de enajenación mental para verificar los pasos procesales a seguir en cada caso:

a) la investigación se encuentra desformalizada y el fiscal considera que existen antecedentes que permiten presumir la inimputabilidad por enajenación mental del imputado; 
b) la investigación se encuentra formalizada (judicializada) y el fiscal o juez consideran que existen antecedentes que permiten presumir la inimputabilidad por enajenación mental del imputado.

La primera situación descrita se plantea ya iniciada la investigación por un delito determinado, pero que aun no se ha formalizado en contra del imputado sospechoso de padecer una enfermedad mental. Puede ocurrir que, aunque existan antecedentes que permitan presumir la inimputabilidad por enajenación mental del imputado, el fiscal decida:

i. Aplicar el principio de oportunidad por concurrir sus presupuestos;

ii. Abstenerse de iniciar o continuar una investigación o archivarla temporalmente, si se dan los supuestos contemplados en los arts. 167 y 168 CPP (aplicables a la especie por la regla de supletoriedad contenida en el art. 456 CPP);

iii. Solicitar el informe psiquiátrico a que se refiere el artículo 458 CPP -aún antes de formalizarlo- para decidir qué vía procesal seguir respecto de dicho imputado, sin perjuicio de continuar la investigación respecto de los demás imputados, si los hubiere. En efecto, la sospecha de inimputabilidad debería desencadenar, en todo caso, el interés del ministerio público a obtener información sobre el real estado del sujeto, cuestión que se vincula al denominado "principio de objetividad" que rige la actividad del ministerio público ${ }^{17}$. Si el juez acoge la solicitud debe, al mismo tiempo, ordenar la suspensión del procedimiento por parte del ministerio público hasta tanto se evacua el correspondiente informe, sin perjuicio de continuarse la investigación respecto de los demás imputados.

La segunda situación concurre una vez que se encuentra formalizada la investigación en contra del inculpado presuntamente inimputable y, por consiguiente, se encuentra interviniendo el competente juez de garantía. En este caso puede suceder que, aunque existan antecedentes que permitan presumir la inimputabilidad por enajenación mental del imputado o de uno de ellos, el fiscal decida:

i. Solicitar al juez de garantía el sobreseimiento definitivo o temporal (parcial o total) de la causa por considerar que concurren sus presupuestos respecto del imputado al parecer enajenado mental (art. 460, inciso $1^{\circ} \mathrm{CPP}$ );

\footnotetext{
17 Por todos ver Horvitz L., María Inés y López M., Julián, Derecho procesal penal chileno, T. 1, Editorial Jurídica de Chile, Santiago, año 2003.
} 
CEJ - El tratamiento del inimputable en el derecho procesal penal chileno

ii. Solicitar al juez de garantía, en audiencia especial convocada al efecto, la realización de un informe psiquiátrico a la institución que corresponda, explicitándose la conducta punible que se investiga en relación al imputado al parecer enajenado mental. Este informe también puede ser solicitado de oficio por el tribunal. En estos casos y mientras el informe no se remita al tribunal, el juez debe ordenar la suspensión del procedimiento, sin perjuicio de continuarse respecto de los demás coimputados, si los hubiere (art. $458 \mathrm{CPP}$ ).

En ambos casos, el fiscal deberá haber agotado la investigación del cuerpo del delito y la participación a lo menos respecto del imputado sospechoso de enajenación mental. Esto aparece evidente en el primer supuesto planteado; en la segunda hipótesis se desprende de dos circunstancias: a) que al solicitarse el informe psiquiátrico opera la suspensión del procedimiento respecto del imputado sospechoso de enajenación mental; y b) que una vez remitido el informe y afirmado la existencia de enajenación mental debe efectuarse un requerimiento de aplicación de un procedimiento especial, el que debe cumplir con las menciones del escrito de acusación. Por consiguiente, debe contarse con todos los antecedentes de la investigación para evacuar dicho trámite y pasar a la etapa de preparación del juicio.

\section{II.2.2. Suspensión del procedimiento e internación provisional}

Como vimos precedentemente, la necesidad de ratificar o negar la sospecha de inimputabilidad que recae sobre el imputado obliga a la suspensión del procedimiento, pues se requiere el pronunciamiento previo de especialistas en la materia. El proceso penal es básicamente un acto comunicativo, que por tanto requiere de sujetos que mantienen una interlocución en claves conocidas por todos los involucrados, que permiten desarrollar actividades en las cuales quienes conminan, interrogan o expresan, reciben del receptor una respuesta, de aceptación, negación, explicación o reserva ${ }^{18}$. Cuando dicha comunicación es deficitaria o nula, bastarán antecedentes indiciarios que acrediten dicha situación para presumir que el sujeto no está en condiciones de defenderse apropiadamente, imponiéndose la suspensión del procedimiento hasta elucidar este aspecto.

La interrogante que pudiera surgir a continuación es la siguiente: ¿podría el fiscal a cargo del caso solicitar alguna medida cautelar personal respecto de un imputado que se sospecha es enajenado mental y, además, peligroso (en el sentido de que podría atentar contra sí mismo o contra terceros) hasta tanto se remita el informe psiquiátrico correspondiente?

\footnotetext{
18 Por todos ver Maier, Julio, Derecho procesal penal, Tomo I, Editores del Puerto, Buenos Aires 2002, $2^{\mathrm{a}}$ ed., pp. 9 y siguientes.
} 
La regla supletoria del artículo 456 CPP remite a las disposiciones del Libro II del CPP, en cuanto no fueren contradictorias con las del Título VII del Libro IV del CPP. Las medidas cautelares personales se regulan en el Libro I del citado cuerpo legal y la única disposición que se refiere a ellas es la contenida en el art. 464 del CPP, que se refiere a la internación provisional del imputado y hace aplicables, en lo pertinente, las normas contenidas en los párrafos $4^{\circ}, 5^{\circ}$ y $6^{\circ}$ del Título V del Libro I.

El inciso primero del artículo 464 CPP establece que:

Art. 464. Internación provisional del imputado. Durante el procedimiento
podrá ordenar, a petición de alguno de los intervinientes, la internación
provisional del imputado en un establecimiento asistencial, cuando concurrieren
los requisitos señalados en los articulos 140 y 141 , y el informe psiquiátrico
practicado al imputado señalare que éste sufre una grave alteración o
insuficiencia en sus facultades mentales que hicieren temer que atentará contra sí
o contra otras personas.

Esto es, la internación provisional del imputado, medida cautelar que podría aplicarse respecto de un inimputable en un procedimiento que tiene como presupuesto la imputación de la comisión de un delito, sólo es procedente cuando: a) concurran en la especie los presupuestos de aplicación de cualquier medida cautelar personal (arts. 140 y $141 \mathrm{CPP}$ ) y, b) del informe psiquiátrico que se practique al imputado, aquél señale que, por su estado mental, éste es peligroso para sí mismo o para terceros.

Por consiguiente, la existencia de meras sospechas de inimputabilidad y peligrosidad obliga a realizar un informe psiquiátrico y, mientras éste se halle pendiente de elaboración y remisión al tribunal, el procedimiento debe suspenderse, sin posibilidad de -ante la duda sobre la imputabilidad- aplicarse una medida cautelar personal general (in dubio pro libertate). Incluso más, si el imputado se encontrare ya sujeto a alguna medida cautelar personal al momento de plantearse las sospechas de inimputabilidad, debe suspenderse su ejecución dejando en libertad al sujeto- hasta la remisión del informe respectivo, a fin de que se decida si se mantiene la medida, se decreta su internación provisional o se le deja en libertad. Pareciera claro que ante la duda de si procede continuar el procedimiento conforme a las reglas generales o un procedimiento especial, debe prevalecer la intangibilidad de los derechos fundamentales ${ }^{19}$, con mayor razón si el legislador ha establecido un procedimiento especial, con mayores presupuestos y garantías, para el evento de que el imputado pudiera ser declarado inimputable.

\footnotetext{
19 Consideramos en este sentido que los derechos fundamentales sirven para limitar la acción punitiva estatal. Esta frase acuñada en la literatura penal desde hace mucho tiempo, hoy se encuentra en un terreno más bien pantanoso. Para una explicación de este paradigma ver Bascuñán R., Antonio, "Derechos Fundamentales y Derecho Penal", conferencia publicada por SELA en http://islandia.law.yale.edu/sela/sbascunan.pdf, (visita del día 25 de enero de 2007).
} 
CEJ - El tratamiento del inimputable en el derecho procesal penal chileno

Por consiguiente, no resultan aplicables, en el ámbito penal, los arts. $130 \mathrm{y}$ 131 del Código Sanitario que autorizan, entre otras, la internación judicial de los enfermos mentales, remitiéndose al reglamento correspondiente ${ }^{20}$. En efecto, el Reglamento $\mathrm{N}^{\mathrm{a}}$ 570, de 1998, publicado en el Diario Oficial el 14 de Julio de 2000, trata en general de todos aquellos casos en que un sujeto requiera de tratamiento psiquiátrico en un establecimiento especializado, ya sea en forma voluntaria o no voluntaria, y en este último caso, la internación puede ser: a) de urgencia; b) administrativa; o c) judicial. El artículo 15 del Reglamento señala que la internación judicial "es aquella dispuesta por resolución de un Tribunal de Justicia". A su turno, el art. 9 señala que:

Para proceder a cualquier tipo de internación u hospitalización de una persona con enfermedad o trastorno mental, la medida deberá ser indicada por un médico cirujano, preferentemente que cumpla las condiciones de médico tratante que señala el artículo 6 número $7 y$, sólo en el evento de no existir este último en la localidad o que, habiéndolo, no sea posible su asistencia profesional, por otros médicos cirujanos. En este caso, la medida deberá ser evaluada y confirmada por un médico tratante o por el mismo, previamente asesorado por aquel, dentro de un plazo de 72 horas, de lo que se dejará constancia en la ficha clínica.

Sólo procederá la internación psiquiátrica cuando concurran una o más de las siguientes condiciones:

- Necesidad de efectuar un diagnóstico o evaluación clínica que no pueda realizarse en forma ambulatoria;

- Necesidad de incorporar a la persona a un plan de tratamiento que no sea posible de llevarse a cabo de una manera eficaz en forma ambulatoria, atendida la situación de vida del sujeto;

- Que el estado o condición psíquica o conductual de la persona represente un riesgo de daño físico, psíquico o psicosocial inminente, para sí misma o para terceros.

Como se aprecia, a nivel reglamentario se plantean una serie de exigencias para la internación psiquiátrica de una persona las que, sin embargo, no son siempre copulativas y que generan dudas sobre la constitucionalidad de los artículos 130 y 131 del Código Sanitario ${ }^{21}$. No obstante, cuando se trata de la

\footnotetext{
20 El Código Sanitario, al posibilitar la internación administrativa del enfermo mental quiebra la regla establecida en el artículo 466 del Código Civil, que señala: "El demente no será privado de su libertad personal, sino en los casos en que sea de temer que usando de ella se dañe a sí mismo, o cause peligro o notable incomodidad a otros. Ni podrá ser trasladado a una casa de locos, ni encerrado, ni atado, sino momentáneamente, mientras a solicitud del curador o de cualquiera persona del pueblo, se obtiene autorización judicial para cualquiera de estas medidas". Aún más, infringe una regla constitucional fundamental, cual es que para poder afectar o perturbar derechos protegidos por la Constitución debe solicitarse aprobación judicial previa (art. $83 \mathrm{CPR}$ ).

${ }^{21}$ Vid. nota precedente.
} 
imputación de un delito, prevalecen las disposiciones de la Constitución (art. 83 inciso $3^{\circ}$ ), que hacen perentoria la aprobación judicial previa de la internación y las del Código Procesal Penal, que prevalecen respecto de las del Código Sanitario: a) por haber sido dictadas con posterioridad a ellas (art. 24 de la Ley sobre efecto retroactivo de las leyes) y; b) porque regulan un procedimiento particular (principio de especialidad) para el caso en que deba decidirse la internación judicial provisoria de un enfermo o enajenado mental a quien se le atribuye la comisión de un delito ${ }^{22}$.

En el procedimiento penal de aplicación de una medida de seguridad, el delito no es fundamento sino motivo de la imposición de la medida, pues el establecimiento de su perpetración en la sentencia permitiría confirmar el pronóstico de que el sujeto podría atentar nuevamente contra sí mismo o contra terceros. A diferencia de los demás casos de internación previstos en el Reglamento ya citado, la internación provisoria durante el procedimiento (art. 464 CPP) o constitutiva de una de las medidas de seguridad a que se refiere el art. 457 del Código Procesal Penal cumplen cabalmente con la exigencia de reserva legal para las medidas coercitivas que implican formas de restricción o privación de libertad $^{23}$.

Por consiguiente, cuando deba decidirse sobre la internación provisional del imputado sospechoso de ser enajenado mental y peligroso, deben cumplirse estrictamente los presupuestos previstos en el artículo 464 CPP; el juez penal no podría ordenar la internación del sujeto en base a lo dispuesto en los arts. 130 y 131 del Código Sanitario y 15 del Reglamento, porque el Código Procesal Penal contiene reglas más exigentes y prevalecen sobre aquéllas ${ }^{24}$; de otro modo, se estaría burlando el estatuto legal especial que establece el Código Procesal Penal. Abona esta interpretación el hecho que, durante la tramitación parlamentaria del CPP, la Cámara de Diputados pretendió introducir, en el art. 455, la frase final "sin perjuicio de lo dispuesto en el Código Sanitario"25. Ante la observación de que el

\footnotetext{
${ }^{22}$ En el mismo sentido Roxin para el caso alemán: "En el procedimiento de internación decide, en general, el juez de jurisdicción voluntaria, quien - a diferencia del juez penal- también puede disponer la internación cuando la peligrosidad del enfermo no ha conducido aún a la comisión de un hecho punible" (cfr. Roxin, Claus, Derecho Procesal Penal (traducción de la $25^{a}$ edición alemana de Gabriela E. Córdoba y Daniel R. Pastor, revisada por Julio B.J. Maier), Editores del Puerto, Buenos Aires, 2000, p. 546).

${ }^{23}$ Cfr. art. $19 \mathrm{~N}^{\mathrm{o}} 7$ CPR. No cabe, a nuestro juicio, argumentar que el principio de legalidad queda salvado con las disposiciones de los arts. 130 y 131 del Código Sanitario, pues este cuerpo legal apenas realiza una clasificación de las formas de internación remitiendo en todo al reglamento, cuyo rango estatutario no provee de la suficiente seguridad jurídica a los ciudadanos (Sobre el principio de legalidad en las medidas cautelares personales, cfr. Horvitz, M.I./ López, J, Derecho procesal penal chileno, cit., T. I, p. 350 y pp. 458 y ss.).

${ }^{24}$ Conforme al art. $9^{\circ}$ del Reglamento $N^{\circ} 570$, se podría internar a un sujeto respecto del cual no existiese un informe psiquiátrico de peligrosidad, porque esta exigencia se prevé de forma alternativa (y no copulativa) con las demás.

${ }^{25}$ Cfr. Pfeffer U, Emilio, Código procesal penal anotado y concordado, Ed. Jurídica de Chile, Santiago, 2001, p. 432.
} 
Código no es el llamado a determinar cómo se tratará a un enfermo mental que no ha cometido delito y es peligroso, un parlamentario puso hincapié en la necesidad de limitar las facultades de los Servicios de Salud al señalar "que no es posible que una autoridad administrativa pueda decidir la internación de una persona, y consecuencialmente privarla de libertad, sin intervención de la autoridad

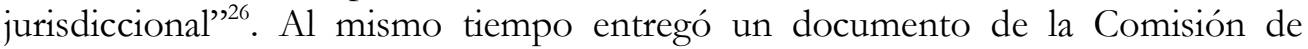
Derechos Humanos del Senado en que se indicaba que alrededor de 75 personas discapacitadas mentales o postrados absolutamente o mayores de 70 años estaban en cárceles comunes ${ }^{27}$. El Senado desechó la preocupación del senador aduciendo que las normas del Código Sanitario no tienen ninguna relación con el proceso penal. Este planteamiento ha permitido la imposición de medidas notablemente aflictivas para los derechos de las personas, como es el internamiento manicomial por tiempo indefinido, al margen de toda garantía constitucional y del control jurisdiccional, sobre la base de que se trata de medidas que no son penas. Esta posición, sin embargo, se opone al rechazo unánime de la doctrina a las medidas de seguridad predelictuales, más aún si ellas son dispuestas por la autoridad administrativa, sosteniendo que se trata de un clásico ejemplo de "fraude de etiquetas"28 que permite eludir el respeto y cumplimiento de las garantías procesales y sustantivas. Por ello, cabe esperar que prospere la propuesta del Senado en orden a "revisar, mantener o perfeccionar" la legislación sanitaria en esta materia ${ }^{29}$.

\section{II.2.3. Oportunidad en que cesa la suspensión y se reanuda el procedimiento en contra del imputado presuntamente enajenado mental}

Una vez decretada la suspensión del procedimiento surge la interrogante de hasta cuándo debe mantenerse esa situación procesal. De acuerdo al texto del propio artículo $458 \mathrm{CPP}$, el juez deberá ordenar la suspensión del procedimiento hasta tanto no se "remitiere" el informe requerido.

$\mathrm{Al}$ parecer las alternativas interpretativas ante este punto pueden resumirse en: a) la suspensión se encuentra justificada hasta que el informe sea enviado por el organismo facultado para emitirlo; b) la suspensión se encuentra justificada hasta tanto sea recepcionado el contenido del informe por cualquier medio fehaciente al juez. La primera alternativa interpretativa dice relación con la significación estricta de la voz "remitir"30, que no comprende, necesariamente, la recepción de la información por el requirente de la misma. Sin embargo, sólo a través de la

\footnotetext{
${ }^{26}$ Ibíd.

${ }^{27}$ Pfeffer, cit., p. 433.

${ }^{28}$ Zaffaroni/Alagia/Slokar, Derecho penal, P.G., $2^{\text {a }}$ ed., Ediar, Buenos Aires, 2002, p. 70.

${ }^{29}$ Así consta de los antecedentes de la tramitación parlamentaria del Proyecto; vid. Pfeffer, cit., p. 433.

${ }^{30}$ A este respecto debe revisarse cual es el significado de la palabra "remitir", así tenemos que de acuerdo a la definición de la Real Academia de la lengua, la expresión "remitir" significa: "Enviar algo a determinada persona de otro lugar", ver www.rae.es.
} 
recepción del informe -el que puede efectuarse por vías informales y rápidas- y del examen de su contenido el fiscal podrá decidir si efectúa un requerimiento de medida de seguridad en los términos del art. $461 \mathrm{CPP}$, si solicita el sobreseimiento definitivo o temporal de la causa (art. 460 inciso $1^{\circ} \mathrm{CPP}$ ) o si insta por la continuación del procedimiento conforme a las reglas generales por considerar que el imputado es plenamente imputable.

Si en base a las conclusiones del informe psiquiátrico, el ministerio público estima concurrente la causal de exención de responsabilidad criminal prevista en el art. $10 \mathrm{~N}^{\circ} 1$ del Código Penal, y además, considera aplicable una medida de seguridad, debe solicitar expresamente al tribunal que se proceda conforme a las reglas previstas en el Título VII del Libro IV del CPP, solicitud que deberá formular por escrito cumpliendo, en lo pertinente, con las menciones del escrito de acusación (art. $461 \mathrm{CPP})^{31}$. También podrá solicitar la internación provisional del imputado si estima que concurren los requisitos contenidos en el artículo 464 CPP.

\section{II.2.4. Designación de curador ad litem}

El artículo 459 CPP dispone lo siguiente:

Art. 459. Designación de curador. Existiendo antecedentes acerca de la enajenación mental del imputado, sus derechos serán ejercidos por un curador ad litem designado al efecto.

La necesidad de curador ad lítem, curaduría especial definida en el art. 494 del Código Civil, se enmarca en el contexto de aseguramiento de derechos y garantías a quien es considerado "incapaz" por el derecho, velando por la protección y custodia de la persona o bienes del pupilo. Esta curaduría corresponde a las personas y en el orden que señala el artículo 462 del mismo cuerpo legal y, a falta de estas personas, tendrá lugar la curaduría dativa. La intervención del guardador en modo alguno afecta la intervención del defensor técnico; por el contrario, es una protección más otorgada al enajenado mental.

Es importante destacar que la designación del curador ad litem procede desde que existen "antecedentes" acerca de la enajenación mental del imputado. Por consiguiente, no es necesario esperar a la remisión del informe psiquiátrico a que se refiere el art. $458 \mathrm{CPP}$. El tribunal, de oficio o a petición de parte, podría efectuar la designación en cualquier estado del procedimiento.

\footnotetext{
31 Vid. infra II.2.6.
} 
CEJ - El tratamiento del inimputable en el derecho procesal penal chileno

\section{II.2.5. Situación particular de la detención por flagrancia del sujeto al parecer enajenado mental y el correlativo control de la detención}

Hemos estimado de la mayor relevancia tratar separadamente la situación del sujeto que, presumiéndose o constando su inimputabilidad, es emplazado al proceso penal, no por medio de una citación -lo que permitiría, en principio, contar con los antecedentes necesarios para instar ab initio por la aplicación del procedimiento especial para inimputables enajenados-, sino a través de su detención por encontrarse en situación de flagrancia.

Sobre este punto, cabe anotar que nuestro Código no contempla normas explícitas a este respecto. En efecto, los artículos 458 y siguientes del CPP, razonan sobre la base de la existencia de un procedimiento (ordinario) en curso, dentro del cual se constata la existencia de antecedentes que hacen presumir la inimputabilidad por enajenación mental. En otras palabras, puede suceder que se haya iniciado el procedimiento ordinario por crimen o simple delito y que, durante su tramitación, surjan las sospechas de inimputabilidad respecto del imputado, habiéndose incluso realizado diligencias intrusivas o decretado medidas cautelares personales. En estos casos procede la aplicación de las disposiciones que hemos examinado precedentemente ${ }^{32}$.

Pero también puede ocurrir que el imputado sea detenido por considerarse que ha incurrido en una situación de flagrancia y surjan antecedentes suficientes de la existencia de un trastorno mental severo en la misma audiencia de control de la detención. La situación procesal en la cual el individuo es puesto, por primera vez, a disposición de un tribunal, sin la existencia previa de una investigación y con antecedentes que sólo dan cuenta preliminarmente de la comisión de un hecho punible es, sin duda, una hipótesis en la cual la actuación del Estado puede representar una mayor posibilidad de vulneración de derechos ${ }^{33}$. Por ello, tiene especial interés la forma en que debe procederse en estos casos y qué medidas pueden o deben adoptarse.

En primer lugar, consideramos absolutamente imprescindible la designación de un curador ad litem en los términos del art. 459 CPP, y también de un defensor técnico (público, en caso de carecer de uno de elección) a los fines de dar debida protección procesal y patrimonial al imputado ${ }^{34}$. En efecto, aunque no constituye un presupuesto de validez de la audiencia, en estos casos la presencia del defensor pareciera indispensable a los fines de, eventualmente, controvertir la licitud de la detención y provocar la inmediata puesta en libertad del detenido, sin

\footnotetext{
32 Vid. Supra II.2.2, respecto a la existencia previa de medidas cautelares personales.

33 Para un análisis relativo al control de detención y su judicialización debe verse Arias V., Cristián, "Control jurisdiccional de la detención" en Revista de Estudios de la Justicia, número 6, editada por el Centro de Estudios de la Justicia, 2006, pp.

34 Especial relevancia puede tener la designación previa de un curador ad lítem en la hipótesis en que ha habido, además, incautación de especies u objetos al imputado detenido in fraganti.
} 
que ni siquiera se plantee la solicitud de un informe psiquiátrico en este momento procesal. En efecto, la licitud de la detención (esto es, que ella se haya realizado en el marco de la Constitución y la ley y en relación a la perpetración de un hecho típico y antijurídico) es una cuestión previa a la determinación de la inimputabilidad y la posible peligrosidad del sujeto ${ }^{35}$. Sólo si la detención es considerada lícita y el ministerio público desea formalizar la investigación en contra del imputado sospechoso de enajenación mental o trastorno mental transitorio puede surgir la necesidad del informe psiquiátrico.

Una vez ordenada la confección del informe debe suspenderse el procedimiento. Por consiguiente, no cabe solicitar una ampliación del plazo de detención (art. $132 \mathrm{CPP}$ ) ni, menos, procederse directamente a formalizar la investigación. Tampoco cabe ningún tipo de medida cautelar en contra del imputado. Como se analizó oportunamente ${ }^{36}$ y en virtud de los términos utilizados por el legislador en el art. 458 CPP (“ordenará"), la norma que establece la suspensión del procedimiento es indudablemente imperativa $-\mathrm{y}$ no facultativapara el tribunal.

Por ello estimamos que, producida la detención en situación de flagrancia de un sujeto respecto del cual existen antecedentes de un trastorno mental, y sin perjuicio de la designación de un curador ad litem y de un defensor público, en su caso, el tribunal deberá suspender la audiencia de control de su detención, siempre que ésta hubiere sido declarada legal o lícita, rechazar por ello mismo cualquiera otra solicitud del ministerio público o del querellante, si lo hubiere, ordenar la elaboración y remisión del informe psiquiátrico a quien corresponda y dejar en libertad al detenido.

Existe, sin embargo, una hipótesis que podría dar lugar a cierta controversia. Es el caso en que, si bien no se cuenta con el informe forense a que se refiere el artículo 458 en relación al artículo 455 del CPP, sí constan otros informes psiquiátricos previos o antecedentes que acreditan la peligrosidad del sujeto derivada de su especial condición de salud mental. Estimamos que estos antecedentes no deberían considerarse suficientes a los efectos de resolverse acerca de la continuación inmediata del procedimiento conforme a las reglas del Título VII del Libro IV del CPP. En efecto, la resolución que ordena la realización del informe forense a que se refiere el art. $458 \mathrm{CPP}$ exige que se explicite "la conducta punible que se investiga" en relación al imputado sospechoso de ser enajenado mental. Por consiguiente, sólo un informe psiquiátrico que considere el hecho punible imputado satisface las exigencias legales; a lo más los otros antecedentes

\footnotetext{
35 Justamente el modelo gradual de la teoría del delito impone, primero, la verificación de si nos encontramos ante una acción típica y antijurídica y, sólo entonces, corresponde comprobar si el sujeto es culpable (imputable) o inculpable (inimputable). La peligrosidad es un presupuesto de aplicación de la medida de seguridad y es posterior lógica y cronológicamente a los demás presupuestos.

36 Vid. supra II.2.2.
} 
CEJ - El tratamiento del inimputable en el derecho procesal penal chileno

podrían ser tenidos en cuenta por los expertos que deben elaborar el correspondiente informe.

\section{II.2.6. Situaciones procesales posibles tras la remisión del informe psiquiatrico}

Si el informe psiquiátrico practicado al imputado da cuenta de su imputabilidad, deberá reanudarse el procedimiento en su contra conforme a las reglas generales ${ }^{37}$. Si, por el contrario, del informe es posible "establecer con certeza" ${ }^{38}$ la inimputabilidad del sujeto pero, al mismo tiempo se afirma que no existe peligro de atentado contra sí mismo o contra terceros, existen dos posibilidades de acuerdo con la interpretación sistemática de los arts. 460 inciso $1^{\circ}$, 461 y 462 , inciso $2^{\circ}$, todos del CPP:

a) si, antes de la solicitud del informe psiquiátrico, el ministerio público hubiere planteado un requerimiento de aplicación de una medida de seguridad en conformidad con el art. 461 CPP, el juez de garantía deberá rechazar formalmente tal requerimiento y el fiscal deberá cerrar su investigación y solicitar el sobreseimiento definitivo del caso;

b) si el fiscal solicitó el informe psiquiátrico o el juez lo decretó de oficio sin formulación previa de requerimiento de una medida de seguridad, el fiscal deberá directamente cerrar su investigación y solicitar el sobreseimiento definitivo del caso. No hay, en este caso, denegación de requerimiento alguno.

Únicamente si el informe psiquiátrico arroja como resultado no sólo la existencia cierta de enajenación mental en el imputado sino una alta probabilidad futura de atentado contra sí mismo o contra terceros (pronóstico positivo de peligrosidad), el juez deberá acceder al requerimiento del ministerio público en orden a que se apliquen las reglas procesales especiales contempladas en el Título VII del libro IV del CPP, a fin de comprobar la existencia del hecho típico y antijurídico que se atribuye al enajenado mental y requerir la imposición de alguna de las medidas de seguridad establecidas en el artículo 457 del CPP (art. 460, inciso $2^{\circ} \mathrm{CPP}$ ). La ley exige que el requerimiento se efectúe cumpliendo las menciones, en lo pertinente, del escrito de acusación (art. $461 \mathrm{CPP}$ ). Asimismo, prohíbe al ministerio público solicitar la aplicación del procedimiento abreviado o la suspensión condicional del procedimiento. Esta prohibición es lógica, pues ambas alternativas del procedimiento se basan en el consentimiento libre, consciente e informado del imputado, presupuesto que nunca podría concurrir en un enajenado mental.

\footnotetext{
${ }^{37}$ Cfr. art. 462 CPP; también vid. Horvitz/López, Derecho procesal penal chileno, T.II, cit., capítulo XII, pp. 554 y ss.

38 Esta exigencia del inciso $1^{\circ}$ del art. 462 CPP impone un alto estándar para establecer la inimputabilidad del sujeto por enajenación mental; por consiguiente, no basta la posibilidad, ni siquiera una alta probabilidad de existencia de la enfermedad.
} 
REJ - Revista de Estudios de la Justicia - No 10 - Año 2008

\section{3. Aplicación del procedimiento especial regulado en el Título VII del Libro IV del Código Procesal Penal}

\section{II.3.1. La internación provisional del imputado y otras medidas cautelares aplicables al enajenado mental ${ }^{9}$}

La internación provisional es una medida cautelar específica del imputado enajenado mental que sólo puede tener lugar "durante el procedimiento" de aplicación exclusiva de medidas de seguridad, esto es, en el lapso que media entre la resolución judicial que aplica este procedimiento especial y la (eventual) adjudicación de una medida de seguridad. Ella se encuentra claramente emparentada con la prisión preventiva, medida cautelar personal aplicable a los imputados imputables.

Una vez reanudado el procedimiento, podrá solicitarse la internación provisoria del imputado, siempre que se cumplan los requisitos señalados en los artículos 140 y 141 del CPP, esto es, que:

a) existan antecedentes que justifiquen la existencia del delito que se investiga;

b) que existan antecedentes que permitan presumir fundadamente que el imputado ha tenido participación en el respectivo delito como autor, cómplice o encubridor, y

c) la necesidad cautelar del imputado, esto es, que existan antecedentes calificados que permitan al tribunal considerar que la internación provisional sea indispensable para el éxito de diligencias precisas y determinadas de investigación, o que la libertad del imputado es peligrosa para la seguridad de la sociedad o del ofendido; y

d) que el informe psiquiátrico practicado al imputado señalare que éste sufre una grave alteración o insuficiencia en sus facultades mentales que hicieren temer que atentará contra otras personas, o contra terceros.

La exigencia separada de los requisitos c) y d) produce ciertas dificultades interpretativas, pues resulta difícil -a excepción del caso de la diligencias pendientes $^{40}$ - imaginar supuestos de peligro para la sociedad o del ofendido que, a la vez, no constituyan un peligro de atentado contra terceros. Esta situación se produce porque tienden a confundirse los criterios peligrosistas en que se asientan los requisitos de las medidas cautelares personales con la peligrosidad (concreta) exigida para concesión de la internación provisional ${ }^{41}$. En efecto, en este último

\footnotetext{
${ }^{39}$ Vid. Supra II.2.2.

40 Aunque también resulta difícil predicar en un enajenado mental algunas de las actividades dolosas que plantea el legislador como presunción de obstaculización de la investigación en el inciso $2^{\circ}$ del art. 140 CPP.

${ }^{41}$ Una crítica a la "formalización" en criterios materiales y objetivos del "peligro para la seguridad de la sociedad" que hace incompatible esta causal de denegación de la libertad durante el
} 
caso se trata de personas inimputables respecto de las cuales, salvo que su enfermedad fuese sobreviniente ${ }^{42}$, no podrían aplicarse buena parte de los criterios (formalizados) de "peligro para la seguridad de la sociedad" que contempla el inciso $3^{\circ}$ del art. $140 \mathrm{CPP}$ y sí los que se refieren al peligro para la seguridad del ofendido o de terceros, los que coinciden con el que se contiene en la letra d) precedentemente señalada (peligro de atentado contra terceros). Más que "peligro para la sociedad" procedería, en estos casos, la introducción de una causal de denegación de la libertad constituida por el "peligro (concreto) para terceros".

En todo caso, el tribunal, al resolver sobre la solicitud de internación provisional del imputado enajenado mental, debe tener a la vista antecedentes calificados que permitan presumir que aquél pueda atentar contra sí mismo o contra terceros, esto es, es importante que el informe psiquiátrico sea completo, científicamente fundado, claro en el desarrollo de sus consideraciones y conclusiones, que explique la relación entre la enfermedad mental que padece el sujeto, el hecho o hechos punibles que se le atribuyen y la peligrosidad de su conducta futura. Si el informe no estuviere debidamente fundado en todos estos aspectos, debiera complementarse con otro. También podrá considerar la existencia de antecedentes previos como conductas peligrosas reiteradas contra terceros o contra sí mismo, diagnósticos médicos que advierten sobre el carácter peligroso de la enfermedad, la ausencia de cuidado, control o vigilancia sobre el sujeto, etc. Es importante, en cualquier caso, que exista proporcionalidad ${ }^{43}$ entre el hecho imputado y la medida de internación provisional, por la importante afectación de derechos que ella supone para el afectado. Si el mismo fin puede obtenerse con una medida menos aflictiva (como la entrega a un familiar o curador), debe preferirse ésta.

Por otro lado, el legislador hace aplicable también a la internación provisional los supuestos de improcedencia de la prisión preventiva contenidos en el artículo 141 CPP, por tratarse, en todos los casos, de delitos de ínfima o menor gravedad que no alcanzarían a tener relevancia como antecedente sintomático de peligrosidad. Nada obstaría, sin embargo, en casos excepcionales y análogos a los

procedimiento -y, en general, de cualquier causal basada en criterios peligrosistas- con la naturaleza de las medidas cautelares personales puede verse en Horvitz/López, Derecho procesal penal chileno, Tomo I, cit, pp. 413 y ss. ; también, vid. Roxin, Claus, Derecho procesal penal, cit., pp. 256 y ss.

${ }^{42}$ Respecto de ellos podría plantearse que se encuentran "sujetos a alguna medida cautelar personal, en libertad condicional o gozando de alguno de los beneficios alternativos a la ejecución de las penas privativas o restrictivas de libertad contemplados en la ley; la existencia de condenas anteriores cuyo cumplimiento se encontrare pendiente, atendiendo a la gravedad de los delitos de que se trataren, y el hecho de haber actuado en grupo o pandilla". En todo caso, el informe psiquiátrico a que se refiere el art. $458 \mathrm{CPP}$ deberá considerar la gravedad del delito que se imputa al enajenado mental y sus circunstancias, y el número de delitos atribuidos y el carácter de los mismos para establecer la peligrosidad del sujeto, en cuanto hechos sintomáticos de la misma.

43 Sobre la importancia de este factor en el ámbito de las medidas de seguridad y de intervención sobre el inimputable, vid. Silva Sánchez, Jesús-María, Perspectivas sobre la política criminal moderna, Ed. Abaco de Rodolfo Depalma, Buenos Aires, 1998, pp. 73 y ss. 
señalados en el inciso final de dicha disposición legal, a decretarse su internación provisional.

Junto a la remisión a las normas de la prisión preventiva, el inciso final del artículo 464 del CPP también remite, entre otros, al párrafo $6^{\circ}$ del Título $\mathrm{V}$ del Libro I del CPP y, por consiguiente, a su artículo 155, esto es, son aplicables a los inimputables, "en lo que fueren pertinentes", las demás medidas cautelares personales previstas para los imputables. En suma, es posible decretar "otras" medidas cautelares personales, distintas a una privativa de libertad completa, como el arresto domiciliario (a cargo de un curador), la sujeción a la vigilancia de una persona o institución determinada, la que debe informar periódicamente al jue $\mathrm{z}^{44} \mathrm{O}$ la prohibición -controlada por un tercero- de aproximarse al ofendido o su familia.

Finalmente, tratándose de la internación provisional y las demás que puedan decretarse en razón del reenvío al art. 155 CPP -todas medidas cuyo fin legítimo es cautelar y asegurar la comparecencia del imputado a las actuaciones del procedimiento y, especialmente, al juicio- ellas deben mantenerse sólo por el lapso en que fueren necesarias. El carácter instrumental y provisional de estas medidas es afirmada por Marín ${ }^{45}$, quien señala que "[...]las medidas cautelares nunca constituyen un fin en sí misma sino que siempre están sujetas a otra providencia cuyos resultados aseguran interinamente." De modo que no sólo es posible alzarlas tan pronto cese el motivo que las hizo procedentes, sino también sustituirlas por otras menos gravosas.

No cabe duda, sin embargo, que tratándose de la internación provisional, ella viene a cumplir las mismas funciones que cumple la prisión preventiva en el procedimiento penal de imputables, entre ellas, la de dar satisfacción (simbólica) a determinadas necesidades psicológicas (punitivas) de la colectividad, función (de pena anticipada) que, evidentemente, no encuentra legitimación en el ámbito de la intervención punitiva en un Estado democrático de derecho ${ }^{46}$. Esta función, unido al hecho que la clientela habitual de inimputables serán personas de escasos recursos y sin redes sociales de apoyo, determinará, en la práctica, que ésta sea la medida cautelar más utilizada del sistema. En tal sentido, es un deber del Estado proveer de establecimientos dignos y aptos para el internamiento provisional de

\footnotetext{
${ }^{44}$ Creemos que la medida contemplada en el art. 155 letra b del CPP constituye una alternativa de extrema utilidad en estos casos, planteándose no obstante la objeción que, ante la habitual inexistencia de personas o instituciones que puedan hacerse cargo gratuitamente de estos imputados, generalmente débiles económicamente o abandonados, esta medida quedará reservada para aquellos que cuenten con respaldo familiar y económico, quedando la internación provisional para los otros.

45 Marín G., Juan Carlos, "Las medidas cautelares en el nuevo Código Procesal Penal chileno", en Revista de Estudios de la Justicia No 1, Centro de Estudios de la Justicia de la Facultad de Derecho de la Universidad de Chile, Santiago, 2002.

${ }^{46}$ Cfr. Silva S., Jesús María, Aproximación al derecho penal contemporáneo, Bosch, Barcelona, 1992, pp. 307 y ss.
} 
CEJ - El tratamiento del inimputable en el derecho procesal penal chileno

estas personas que, salvo situaciones de emergencia y por su condición procesal de imputados, no podrían ser objeto de un tratamiento psiquiátrico ${ }^{47}$.

\section{II.3.2. Actuaciones posteriores del procedimiento especial.}

Si el juez de garantía, acogiendo el requerimiento del ministerio público que se efectúa en conformidad con el art. $461 \mathrm{CPP}$, declara que el imputado se encuentra en la situación prevista en el artículo $10 \mathrm{~N}^{0} 1$ del Código Penal y corresponde aplicar una medida de seguridad, deberá continuarse el procedimiento penal conforme a las reglas especiales contempladas en el Título VII del Libro IV del CPP (art. 462 CPP). Una de ellas es que el procedimiento no se podrá seguir conjuntamente contra sujetos enajenados mentales y otros que no lo fueren (art. 463 letra a) CPP). De allí que las acusaciones deducidas en contra de coimputados por el mismo hecho deban dar lugar a un juicio oral separado. Sin perjuicio de lo anterior, cabe señalar que, como el procedimiento ordinario es de aplicación supletoria, podrán debatirse y resolverse en la audiencia de preparación del juicio oral las solicitudes y correcciones que se hubieren planteado en los respectivos escritos de requerimiento y de contestación a los mismos. Finalmente, el juez de garantía dictará el auto de apertura del juicio oral.

El juicio oral, que debe desarrollarse ante el competente tribunal de juicio oral en lo penal, se tramita conforme a las reglas del procedimiento ordinario, con la particularidad que debe realizarse a puerta cerrada, sin la presencia del enajenado mental, cuando su estado imposibilite la audiencia (art. 463 letra b) CPP). La redacción de la norma ofrece dudas ${ }^{48}$. Sobre su sentido para el legislador, sólo existe constancia de una intervención en la Cámara de Diputados, en la que se estableció que la disposición constituye una medida de protección para el enfermo mental, por estimarse que "exigirle que interactúe con las personas que no son enfermas mentales puede ponerlo en situaciones que no corresponden" ${ }^{49}$. Pareciera que la restricción de carácter general en los juicios contra enajenados mentales se refiere únicamente a la publicidad del juicio. Sin embargo, mientras no exista peligro de atentado contra sí mismo o terceros no puede negarse al acusado su derecho a estar presente en el juicio dirigido contra su persona.

En consecuencia, la única medida de protección admisible sería la realización del juicio a puerta cerrada, para evitar perturbaciones en el desarrollo

\footnotetext{
47 Nótese que el inciso $5^{\circ} \mathrm{del}$ art. $481 \mathrm{CPP}$ distingue entre establecimientos psiquiátricos o instituciones donde los enajenados mentales "se encontraren internados o se hallaren cumpliendo un tratamiento (...), en virtud de las medidas de seguridad que se les hubieren impuesto (...)". Esta segregación se impone por su diferente estatus jurídico-procesal, el mismo que concurre entre presos preventivos y condenados.

${ }^{48}$ La confusión se produce por la ubicación de las comas, que permiten formar dos frases con sentido diferente: a) el juicio debe realizarse a puerta cerrada y sin la presencia del enajenado mental sólo y cuando su estado imposibilite la audiencia, o b) el juicio debe realizarse (siempre) a puerta cerrada, (pero) sin la presencia del enajenado mental cuando su estado imposibilite la audiencia. ${ }^{49}$ Pfeffer, cit., p. 438.
} 
de la audiencia, provenientes del público. Una restricción adicional y excepcional estará constituida por la posibilidad de que el juicio se desarrolle sin la presencia del acusado enajenado mental, "cuando su estado imposibilite la audiencia", esto es, cuando por las características particulares de su enfermedad no pueda desarrollarse normalmente la audiencia o pueda atentar contra sí mismo o terceros, etc.

\section{II.4.- Situación especial: la inimputabilidad del imputado no es reconocida por el juez de garantía pero constituye alegación de fondo por parte de la defensa en el juicio oral}

Hasta ahora se ha discurrido sobre la base de hipótesis en las que el Ministerio Público indaga y reconoce, desde las etapas preliminares del procedimiento, la calidad de inimputable de un sujeto, y por consiguiente, su tarea se centrará -si no ha optado derechamente por solicitar el sobreseimiento definitivo de la causa- en acreditar el hecho antijurídico y la participación en él del imputado. Por su parte, el juez de garantía aprobará el requerimiento de aplicación de una medida de seguridad si considera que el imputado, además de inimputable es una persona que puede atentar contra sí mismo o contra terceros.

Sin embargo, en un número importante de casos el objeto central del debate en el juicio oral será, justamente, la determinación de la calidad de inimputable o no del acusado. Nos referimos específicamente a la hipótesis en la cual el sujeto ha tenido el tratamiento jurídico-penal de imputable durante todo el procedimiento (habiéndose eventualmente rechazado dicha calidad en la etapa de investigación preliminar) y la tesis de la defensa se basa en la inculpabilidad del acusado por demencia o enajenación mental, solicitando su exención de responsabilidad criminal en conformidad al artículo $10 \mathrm{~N}^{\circ} 1$ del Código Penal.

Como es fácil concluir, en estos casos el Tribunal Oral en lo Penal deberá decidir, de modo principal, si el acusado, al momento de cometer el hecho imputado, era o no capaz de culpabilidad. Si se prueba en el juicio y el tribunal adquiere la convicción de que el sujeto era imputable al momento de cometer el hecho (plenamente o en forma mitigada) no se presenta ninguna dificultad, pues entonces deberá desechar la alegación de inimputabilidad de la defensa e imponer la pena que corresponda por la infracción atribuida y sus circunstancias. Tampoco habrá problema procesal especial alguno si el tribunal absuelve al no dar por establecido el hecho punible o la participación del acusado en él.

Sin embargo, la situación será más problemática si durante el curso del juicio oral el tribunal adquiere la convicción de que, estando acreditado el hecho antijurídico y la participación del acusado, éste no es imputable por demencia o enajenación mental. En este caso no cabe otra solución adjudicativa que la absolución en virtud de lo dispuesto en el artículo $10 \mathrm{~N}^{\circ} 1$ del Código Penal. Por consiguiente, en caso alguno podría decidirse la aplicación de una medida de seguridad en contra del sentenciado, por las siguientes razones: 
CEJ - El tratamiento del inimputable en el derecho procesal penal chileno

Primero, porque no habiéndose aplicado en su oportunidad el procedimiento especial de imposición de una medida de seguridad, ha precluido procesalmente tal posibilidad y, conectado con lo anterior, porque ha debido probarse la peligrosidad del acusado, elemento que constituye presupuesto indispensable para la aplicación de una medida de seguridad postdelictual. Tal circunstancia sólo podría acreditarse a través del informe psiquiátrico a que se refiere el artículo $458 \mathrm{CPP}$, pues él permite verificar la posibilidad de atentado contra sí mismo o contra terceros por parte del enfermo mental.

En efecto, el artículo $1^{\circ}$ del CPP establece que tanto en la imposición de una pena como de una medida de seguridad, deberá actuarse con arreglo al procedimiento establecido previamente por la ley para dicho efecto, principio de la reforma que halla su fundamento constitucional en el artículo $19 \mathrm{~N}^{\circ} 3$ inciso $4^{\circ}$ de la Carta Fundamental. Por otro lado, el legislador ha establecido un procedimiento especial, con mayores garantías, para la aplicación de una medida de seguridad pues se trata del juzgamiento y aplicación (eventual) de medidas respecto de quien carece de las aptitudes y facultades intelectuales o mentales necesarias para defenderse cabal y apropiadamente de la imputación jurídico-penal que le practica el Estado. Ello explica que el procedimiento especial que examinamos se aplique tanto a quien era inimputable cuando cometió el hecho antijurídico como al que, con posterioridad, cae en enajenación mental o demencia. No basta tampoco, como es evidente, con la declaración de inimputabilidad para la imposición de una medida de seguridad: debe, además, acreditarse su peligrosidad durante el juicio oral. Dicha tarea corresponde al ministerio público, quien no podrá probar tal extremo ni menos acompañar informes médicos o psiquiátricos al efecto una vez comunicada la decisión de absolución.

\section{Adjudicación de las medidas de seguridad}

\section{III.1. Clases de medidas de seguridad}

Es el Código Procesal Penal, y no el Código Penal, el cuerpo legal que se encarga de describir de manera genérica cuáles son las medidas de seguridad que pueden llegar a imponerse en el caso de encontrarnos ante un sujeto inimputable a quien se le atribuya la comisión de un hecho típico y antijurídico ${ }^{50}$.

En este sentido el artículo 457 del CPP, en lo pertinente, establece que:

\footnotetext{
50 Esta situación tiene razones históricas, pues el $\mathrm{CP}$, de raigambre clásico liberal, nunca se preocupó de las medidas de seguridad como consecuencia posible por la comisión de un delito. En efecto, a diferencia de otros páises latinoamericanos, como México o Argentina, la ideología de la Scuola Positiva y sus propuestas se mantuvo, como señala Politoff, "en los límites de la retórica académica” (Politoff, Sergio: Derecho penal, T.I, Conosur, Santiago, 1997, p. 91).
} 


\section{Art. 457. Clases de medidas de seguridad. Podrán imponerse al enajenado mental, según la gravedad del caso, la internación en un establecimiento psiquiátrico o su custodia y tratamiento (...)}

Como se aprecia, el legislador chileno admite únicamente dos tipos de medidas de seguridad respecto de un sujeto inimputable a quien se le atribuye la comisión de un hecho típico y antijurídico, sin perjuicio de que otras consecuencias jurídicas que leyes penales especiales asignan a la infracción de normas también puedan ser entendidas como tales ${ }^{51}$. Ellas son las siguientes:

a) Internación en establecimiento psiquiátrico;

b) Custodia y tratamiento.

La internación en un establecimiento psiquiátrico es una medida privativa de libertad. La diferencia con las penas de encierro se encuentra en la finalidad del padecimiento. En el caso de la medida de seguridad, la privación de libertad se justifica en su carácter terapéutico y, por consiguiente, en su función preventivo especial; el "castigo", en estos casos, no tiene sentido aunque ciertamente la internación posee un contenido aflictivo para el afectado y éste debe ser evitado al máximo. Tampoco cumple una función preventivo-general, pues los sujetos "normales" consideran distintos a los inimputables: la comisión de delitos por éstos no afecta su confianza en la vigencia de las normas y en la seriedad de la amenaza contenida en las conminaciones penales. En el caso de la pena privativa de libertad, si bien se plantea (aunque críticamente) su necesaria orientación resocializadora, suelen ser más reconocidas sus funciones de retribución, por el hecho cometido culpablemente, y de prevención general ${ }^{52}$.

Por otro lado, el CPP establece un orden de gravedad entre estas dos medidas. La internación es más intensa desde la perspectiva de los intereses constitucionales afectados, $\mathrm{y}$, en los casos en que el mérito de los antecedentes no haga aconsejable la internación, resta la custodia y tratamiento, menos intensa como puede colegirse de las reglas de ejecución que permiten la entrega del enajenado mental, por ejemplo, a la familia.

\section{III.2 Adjudicación de una medida de seguridad en la sentencia}

Al momento de dictar sentencia, el tribunal del juicio deberá adquirir convicción, más allá de toda duda razonable, de que se cometió un hecho típico y antijurídico y que el imputado tuvo participación en él. Por ello, la letra c), primera parte, del artículo $463 \mathrm{CPP}$ establece, como regla especial, que el

\footnotetext{
${ }^{51}$ Sobre este tema, vid. Horvitz/López, Derecho procesal penal chileno, T. II, cit, pp. 554 y ss.

52 Vid. Silva S., Jesús María, "Consideraciones sobre las medidas de seguridad a propósito de su regulación en el nuevo Código penal español”, en, del mismo: Perspectivas sobre la política criminal moderna, cit, pp. 75-76.
} 
tribunal deberá absolver al imputado si no constata, en la sentencia, la existencia de ambos extremos.

El legislador sólo admitió las medidas de seguridad postdelictuales; por consiguiente, debe comprobarse en el juicio la existencia de un hecho que se encuentre descrito en un tipo legal y sea, además, antijurídico. Esta exigencia ratifica el carácter de consecuencia jurídico penal de las medidas de seguridad y, por consiguiente, la proscripción de toda manifestación de un derecho penal de autor por exigencias del Estado de Derecho ${ }^{53}$. Este rasgo del sistema es de la mayor relevancia, pues en virtud de él sólo es procedente la afectación de derechos de un sujeto inimputable en la medida en que se satisfagan estándares relativos al hecho. Las puras consideraciones personales y un trastorno mental intenso no son suficientes para afirmar la procedencia de la medida de seguridad. El estándar de convicción acerca de la existencia del hecho punible y la participación del imputado en él es tan exigente como en el caso de los imputables. Si éste no se satisface por insuficiencia probatoria, por concurrir alguna causal de exención o extinción de la responsabilidad penal (por ejemplo, la legítima defensa o la prescripción de la acción penal) o por convicción acerca de la inocencia del imputado, el tribunal deberá dictar sentencia absolutoria.

Por su lado, la segunda parte de la letra c) del art. 463 CPP dispone que si el tribunal adquiere convicción, en los términos del artículo 340 CPP, acerca de la existencia del injusto y la participación en él del imputado, podrá imponer al inimputable una medida de seguridad. Ello constituye, pues, una facultad del tribunal, pues podría estimar, en base a las pruebas producidas en el juicio, que el sujeto no es peligroso en los términos que exige la ley y que, por lo tanto, no se justifica la aplicación de ninguna medida de seguridad. También podría resolver la aplicación de otra menos intensa, si estima que la medida solicitada por el fiscal es desproporcionada con el hecho cometido y el pronóstico de peligrosidad.

A la luz de lo señalado precedentemente, ¿cabría la dictación de una sentencia absolutoria en la hipótesis de que se establezca la comisión del delito y la participación en él del imputado pero se considere innecesaria la aplicación de una medida de seguridad? En rigor, se trata de un tertium genus que impone al tribunal el pronunciamiento de una sentencia declarativa que afirma la comisión del hecho ilícito pero que, acto seguido, desestima la medida de seguridad solicitada por el ministerio público o el querellante, en su caso. Este supuesto puede ser muy relevante para los efectos de la responsabilidad civil derivada del hecho punible, pues, como es sabido, la fuente de esta responsabilidad es el hecho antijurídico

\footnotetext{
${ }^{53}$ Un procedimiento para aplicación de medidas de seguridad inserto en un Estado Democrático de Derecho debe encontrar fuertes limitaciones a la aplicación de tales medidas, evitando la aplicación de medida "pre-delictuales", situando el punto en la consideración del hecho expresivo de antijuridicidad cometido por el inimputable. Para una explicación acabada del punto debe verse Horvitz L., María Inés y López M., Julián en Derecho procesal penal chileno, cit., Tomo II, pp. 561 y siguientes.
} 
que causa daño. Es perfectamente posible deducir la acción civil dentro de este procedimiento especial, si bien sólo podrá dirigirse en contra del imputado representado por su curador. Si se quiere dirigir la acción en contra de los terceros civilmente responsables, ella sólo podrá entablarse en sede civil (art. 59 CPP).

En el caso de que el tribunal decida imponer al imputado alguna de las medidas de seguridad que prevé el CPP, deberá, además, tener en cuenta las reglas contenidas en los incisos primero y segundo del artículo 481 CPP. Si bien la disposición citada está situada en el apartado referido a la ejecución de las medidas de seguridad, ella contiene normas muy relevantes sobre el límite temporal de las medidas de seguridad, el que debe ser fijado por el tribunal en la sentencia. En efecto, ellas señalan que las medidas de seguridad:

(...) sólo podrán durar mientras subsistieren las condiciones que las bubieren
hecho necesarias, y en ningún caso podrán extenderse más allá de la sanción
restrictiva o privativa de libertad que hubiere podido imponérsele o del tiempo
que correspondiere a la pena minima probable, el que será señalado por el
tribunal en su fallo.
Se entiende por pena minima probable, para estos efectos, el tiempo mínimo de
privación o restricción de libertad que la ley prescribiere para el delito o delitos
por los cuales se bubiere dirigido el procedimiento en contra del sujeto enajenado
mental, formalizado la investigación o acusado, según correspondiere.

Sin embargo, esta disposición plantea una importante interrogante: si necesariamente debe establecerse en la sentencia la existencia (precisa y determinada) del (de los) delito(s) imputado(s) al enajenado mental y su participación en él (ellos) para la aplicación de una medida de seguridad, ¿Qué sentido tiene hablar de "pena mínima probable"? y ¿por qué se recurre a criterios como la formalización o la acusación para determinar esa pena mínima probable y, con ello, el límite temporal de la medida?

Nos parece que esta norma se sostenía en el contexto del antiguo sistema de enjuiciamiento criminal, que no exigía el establecimiento del delito y la participación como presupuesto de aplicación de una medida de seguridad. En el actual sistema, la disposición es superflua, siempre habrá la forma de establecer el límite temporal de la "sanción restrictiva o privativa de libertad que hubiere podido imponérsele" de haber sido plenamente imputable. Es más, en virtud de esta misma norma que se refiere a la sanción "concreta" aplicable al caso, deberán considerarse las circunstancias modificatorias de responsabilidad penal que fueren procedentes y pudieran concurrir en el caso (por ejemplo, la atenuante del art. 11 $\mathrm{N}^{\mathrm{o}} 6 \mathrm{CP}$ que, en general, se valora de un modo objetivo).

\section{III.3. Impugnación de la sentencia que establece una medida de seguridad}

La sentencia que impone o rechaza la aplicación de una medida de seguridad al imputado es impugnable por la vía del recurso de nulidad, pues a falta 
de norma expresa y de remisión al Libro III, sobre recursos, y siendo aplicables supletoriamente las disposiciones del Libro II del CPP, sobre juicio oral, debe entenderse que sólo procede el único medio de impugnación que el legislador admite contra sentencias dictadas en juicios orales.

Naturalmente, dicho recurso será también procedente para el caso que se dicte una sentencia absolutoria por el Tribunal Oral en lo Penal, fundada en la causal de exención de responsabilidad criminal contemplada en el artículo $10 \mathrm{~N}^{\circ} 1$ del Código Penal, pero imponiendo al sentenciado una medida de seguridad ${ }^{54}$.

En efecto, la sentencia que absolviendo al acusado por exclusión de su culpabilidad impone, no obstante, una medida de seguridad sin haberse cumplido con todos los requisitos y trámites del procedimiento establecido para dicho efecto es, a nuestro juicio, impugnable por vía de recurso de nulidad fundado en la causal establecida en el artículo 373 letra a) del CPP, pues por esta vía se habrá vulnerado la garantía a un debido proceso legalmente tramitado, esto es, conforme a las normas establecidas por el legislador para la imposición de una medida de esta naturaleza, vulnerándose de esta forma, y como ya hemos expresado, la garantía constitucional establecida en el art. $19 \mathrm{n}^{\circ} 3$ inciso $4^{\circ}$ de la CPR y recepcionada legalmente en el artículo $1^{\circ}$ del CPP.

Una hipótesis interesante es aquella en que el tribunal oral en lo penal, conociendo del juicio y fruto de su libertad de valoración de prueba, adquiere la convicción de que el sujeto es imputable, ya al momento de comisión del hecho atribuido o al momento del juicio. En otras palabras, ¿qué ocurre cuando el sujeto ya no podría o no debería ser acreedor de una medida de seguridad sino de una pena conforme a la convicción alcanzada por el tribunal? En nuestra opinión, la solución pasa única y exclusivamente por la declaración de nulidad del juicio ${ }^{55}$.

En efecto, habiéndose fijado por el tribunal competente -el respectivo juez de garantía- el objeto del juicio, el tribunal queda limitado en el conocimiento del asunto, pudiendo tan sólo pronunciarse acerca de la procedencia o improcedencia de la medida de seguridad ${ }^{56}$. Si por el contrario el tribunal se pronuncia sobre la capacidad de culpabilidad del sujeto, estimamos que se vulneraría la regla establecida en el artículo 341 inciso $1^{\circ}$ del CPP, dando con ello lugar a la configuración de la causal de nulidad establecida en el artículo 374 letra f).

\footnotetext{
54 Vid. Supra II.4.-

55 Horvitz L., María Inés y López M., Julián, op. cit, p. 573.

56 Salvo que el exista acusador particular o la medida haya sido solicitada de manera subsidiaria, conforme lo permite el artículo 462 inciso final, por cuanto en estas hipótesis, será materia del debate de las partes la imputabilidad del sujeto, caso en el cual no se produciría ninguna afectación al derecho de defensa.
} 
REJ - Revista de Estudios de la Justicia - No 10 - Año 2008

\section{Breves consideraciones acerca de la ejecución de las medidas de seguridad}

\section{IV.1. Presupuestos de la ejecución}

Como sabemos, la ejecución de las penas y medidas de seguridad es un punto que, desde una perspectiva político-criminal, se encuentra en entredicho desde ya largo tiempo en Chile ${ }^{57}$.

Es un hecho, por otra parte, el abandono constante en que se encuentran las personas destinadas a cumplir una pena o medida de seguridad, y la urgente necesidad de producir un proceso de reforma drástico en el ámbito legal, que se haga cargo de las deficientes condiciones padecidas por los sujetos condenados en Chile ${ }^{58}$.

Sin perjuicio de lo anterior creemos que dentro de los márgenes de este informe lo relevante será analizar las escasas normas existentes en la materia.

Nuestro sistema procesal penal se hace cargo del punto en el artículo 481 del CPP. En lo pertinente, estas disposiciones establecen que:

Art. 481. Duración y control de las medidas de seguridad.

(...) La persona o institución que tuviere a su cargo al enajenado mental deberá informar semestralmente sobre la evolución de su condición al ministerio público y a su curador o a sus familiares, en el orden de prelación mencionado en el artículo 108.

"El ministerio público, el curador o familiar respectivo podrá solicitar al juez. de garantía la suspensión de la medida o la modificación de las condiciones de la misma, cuando el caso lo aconsejare.

Sin perjuicio de lo anterior, el ministerio público deberá inspeccionar, cada seis meses, los establecimientos psiquiátricos o instituciones donde se encontraren internados o se hallaren cumpliendo un tratamiento enajenados mentales, en virtud de las medidas de seguridad que se les bubieren impuesto, e informará del resultado al juez de garantía, solicitando la adopción de las medidas que fueren necesarias para poner remedio a todo error, abuso o deficiencia que observare en la ejecución de la medida de seguridad.

El juez de garantía, con el solo mérito de los antecedentes que se le proporcionaren, adoptará de inmediato las providencias que fueren urgentes, y citará a una audiencia al ministerio público y al representante legal del

\footnotetext{
$57 \mathrm{Al}$ menos desde 1993 con la publicación del "Informe de la Comisión especial investigadora de los problemas carcelarios del país”, publicado en El Sol en la ciudad, AA.VV., Comisión Chilena de Derechos Humanos.

58 Al respecto ver Valenzuela S., Jonatan, "El estado actual de la reforma penitenciaria en Chile", en Revista de Estudios de la Justicia $\mathrm{N}^{\circ}$ 6, editada por el Centro de Estudios de la Justicia, año 2006.
} 
CEJ - El tratamiento del inimputable en el derecho procesal penal chileno

enajenado mental, sin perjuicio de recabar cualquier informe que estimare necesario, para decidir la continuación o cesación de la medida, o la modificación de las condiciones de aquélla o del establecimiento en el cual se llevare a efecto.

Por su parte, el artículo 457 del CPP establece:

(...) En ningún caso la medida de seguridad podrá llevarse a cabo en un establecimiento carcelario. Si la persona se encontrare rechida, será trasladada a una institución especializada para realizar la custodia, tratamiento o la internación. Si no lo bubiere en el lugar, se habilitará un recinto especial en el hospital público más cercano.

Como se advierte, estas normas están estructuradas, fundamentalmente, en torno al establecimiento de deberes concretos para los entes públicos comprometidos en la ejecución de las medidas, especialmente cuando se trata de la internación en un establecimiento psiquiátrico, por la relación pública de sujeción en la que se encuentra el afectado. Así tenemos que:

i. La ejecución de la medida de seguridad de internación en un establecimiento psiquiátrico debe ejecutarse en un lugar que "en ningún caso" puede ser un establecimiento carcelario, deber que no siempre ha sido respetado por el Estado chileno $^{59}$. Para mayor detalle la recomendación que se desprende de este sistema de reglas es que, conforme al inciso segundo del artículo $457 \mathrm{CPP}$, dicha medida se ejecute en el recinto más especializado posible desde el punto de vista médico, y en caso de no existir éste se prefiera el hospital público más cercano. En caso de tratarse de la medida de custodia y tratamiento deberá entregarse al sujeto a su familia, a su guardador, o a alguna institución pública o particular de beneficencia, socorro o caridad en su caso.

ii. Una vez definido el lugar, las personas a cargo del inimputable tiene el deber de informar periódicamente el estado del sujeto. Tal como aparece descrito en el artículo 481 del CPP, las personas que puedan tener a su cargo al inimputable en cumplimiento de una medida de seguridad, deben informar al ministerio público y a su curador o a sus familiares, en el orden de prelación mencionado en el artículo $108^{60}$.

\footnotetext{
59 Vid. recursos de protección planteados e instrumentos internacionales suscritos por Chile y vigentes que lo obligan en este aspecto. A este respecto conviene consultar Stippel, Jörg, Las cárceles y la buisqueda de una política criminal para Chile, LOM, 2006.

${ }^{60}$ Como se sabe el artículo 108 establece el concepto amplio de víctima en el sistema procesal penal chileno en los siguientes términos: “Art. 108. Concepto. Para los efectos de este Código, se considera víctima al ofendido por el delito.

En los delitos cuya consecuencia fuere la muerte del ofendido y en los casos en que éste no pudiere ejercer los derechos que en este Código se le otorgan, se considerará víctima:

a) al cónyuge y a los hijos;

b) a los ascendientes;
} 
iii. Siempre existe la posibilidad de suspender la medida o promover la modificación de las condiciones de aplicación de la misma, facultades que pueden ser ejercidas por el ministerio público, el curador o la familia. Esto es claro dado el sentido de la aplicación de la medida de seguridad que conforme al mismo artículo 481 establece que "[...] sólo podrán durar mientras subsistieren las condiciones que las hubieren hecho necesarias [...]". En efecto, en la medida que el fundamento de la medida de seguridad es la peligrosidad del sujeto mostrada sintomáticamente en la comisión del hecho antijurídico, ella puede desaparecer total o parcialmente gracias al tratamiento terapéutico al que haya sido sometido. Esta situación puede dar lugar al cese de la ejecución de la medida o su sustitución por una más benigna.

iv. Existe un deber de control de las condiciones de ejecución de parte del ministerio público. Tal como aparece en el mismo artículo $481 \mathrm{CPP}$, al menos una vez cada seis meses el ministerio público debe inspeccionar todo lugar donde se encuentre una persona en cumplimiento de una medida de seguridad. Correlativamente se establece un deber de información al juez de garantía competente en la ejecución de la medida (art. 466 CPP) del resultado de su inspección solicitando, si fuere necesario, la adopción de medidas para poner remedio a todo error, deficiencia o abuso ejercido sobre los afectados por la medida. El incumplimiento de este deber podría dar lugar, de oficio, a solicitud del defensor o del curador, en su caso, a una audiencia especialmente convocada al efecto, previa citación de los intervinientes, para los efectos de remediar prontamente la situación, cautelar los derechos de los eventualmente afectados, recabar cualquier informe que considerare necesario, establecer las responsabilidades del caso y adoptar las medidas que correspondieren conforme a la ley, entre ellas, la de efectuar la correspondiente denuncia a las autoridades superiores del ministerio público en conformidad con los arts. 48 y ss. de la Ley $\mathrm{N}^{\circ}$ 19.640, Orgánica Constitucional del Ministerio Público. Estas facultades se desprenden del inciso final del art. $481 \mathrm{CPP}^{61}$.

v. El control jurisdiccional es realizado por el juez de garantía que conoció de la fase preliminar e intermedia (art. $466 \mathrm{CPP}$ ). Conforme al artículo $481 \mathrm{CPP}$, el juez de garantía se encuentra llamado por la ley a tomar las providencias necesarias para la corrección de todos los vicios en que se incurra por cualquier autoridad o persona durante la ejecución de las medidas. Dicho tribunal puede ordenar la modificación de condiciones, citar a audiencias y tomar en general cualquier medida correctiva en protección del sujeto inimputable en cumplimiento de una determinada medida de seguridad.

\footnotetext{
c) al conviviente;

d) a los hermanos, y

e) al adoptado o adoptante."

${ }^{61}$ Cfr. art. 14 letra f) del Código Orgánico de Tribunales.
} 
CEJ - El tratamiento del inimputable en el derecho procesal penal chileno

vi. En caso de caer el imputado en enajenación mental durante la condena debe procederse a la sustitución de la pena por una medida de seguridad. Conforme al artículo $482 \mathrm{CPP}$, existe la posibilidad de sustituir la pena por una medida de seguridad en el caso de enfermedad mental sobreviniente a un reo después de dictada la sentencia.

\title{
V. Reglas particulares para el sujeto que cae en enajenación mental durante el procedimiento ${ }^{62}$
}

El artículo 465 del CPP dispone:

\begin{abstract}
Art. 465. Imputado que cae en enajenación durante el procedimiento. Si, después de iniciado el procedimiento, el imputado cayere en enajenación mental, el juez de garantía decretará, a petición del fiscal o de cualquiera de los intervinientes, previo informe psiquiátrico, el sobreseimiento temporal del procedimiento hasta que desapareciere la incapacidad del imputado o el sobreseimiento definitivo si se tratare de una enajenación mental incurable.

La regla anterior sólo se aplicará cuando no procediere la terminación del procedimiento por cualquier otra causa.

Si en el momento de caer en enajenación el imputado se bubiere formalizado la investigación o se bubiere deducido acusación en su contra, y se estimare que corresponde adoptar una medida de seguridad, se aplicará lo dispuesto en el Párrafo $2^{\circ}$ de este Título.
\end{abstract}

Esta hipótesis se diferencia de la anteriormente examinada en que el imputado era capaz de culpabilidad o imputable al momento de cometerse el hecho punible, pero cae en enajenación mental después de iniciarse el procedimiento en su contra. En efecto, la causal de exención de responsabilidad criminal contemplada en el artículo $10 \mathrm{~N}^{0} 1$ del Código Penal se funda en la ausencia de capacidad de culpabilidad del sujeto al momento de cometer el hecho y, por tanto, la imposibilidad de hacerlo responsable penalmente, situación que determinará, por regla general, el sobreseimiento definitivo de la causa por aplicación del art. 250 letra c) CPP, excepto cuando sea necesario aplicar una medida de seguridad. En efecto, si bien no existirían razones preventivo-generales para imponerle una pena ${ }^{63}$, sí podría haber una necesidad

\footnotetext{
${ }^{62}$ En esta sección nos remitimos por completo a lo ya señalado en: Horvitz/López, Derecho procesal penal chileno, T.II, cit., pp.

${ }^{63}$ Es interesante observar que, al momento de cometer el delito, el sujeto era plenamente imputable; por consiguiente, se hacía necesaria la pena y, por consiguiente, no caben aquí los fundamentos dados por la doctrina para prescindir de la dimensión comunicativo-simbólica de la pena. Sin embargo, si sobreviene al sujeto infractor una enfermedad mental en los términos de "volverlo" inimputable, la pena se torna inútil a su respecto y también pierde su necesidad preventivo general y es necesario, eventualmente, sustituirla por una medida de seguridad: en estos casos, a lo más se reacciona ante la frustración de una expectativa cognoscitiva, no normativa; esto es, la medida de seguridad pretende resolver cognoscitivamente el conflicto, a
} 
preventivo-especial que justificase la imposición de una medida de seguridad, como un tratamiento específico. Por su lado, el individuo que cometió el hecho culpablemente, pero que en algún momento posterior a su consumación cae en enajenación mental se halla sujeto a un tratamiento procesal y punitivo similar al anterior, pero por razones diferentes. Se trata, en la especie, de la enajenación mental como una causal de incapacidad procesal sobreviniente, esto es, la ausencia de condiciones psíquicas o mentales para representar racionalmente sus intereses, ejercer sus derechos y conducir su defensa de forma inteligente o inteligible. Pero como respecto de este individuo también puede existir un pronóstico de peligrosidad futura, la ley también contempla la posibilidad de aplicar medidas de seguridad en esta hipótesis.

En el caso de enajenación mental sobreviniente, y de conformidad con lo dispuesto en el inciso $1^{\circ}$ del art. $465 \mathrm{CPP}^{64}$, el juez de garantía deberá decretar, a petición del fiscal o de cualquiera de los intervinientes y previo informe psiquiátrico, el sobreseimiento temporal del procedimiento hasta que desaparezca la incapacidad del imputado o el sobreseimiento definitivo, si se trata de una enajenación mental incurable. Esta regla sólo se aplicará cuando no proceda la terminación del procedimiento por cualquier otra causa, con la limitación que plantea el inciso $2^{\circ}$ del artículo $461 \mathrm{CPP}$.

Asimismo, no procederá el sobreseimiento temporal o definitivo si, al momento de caer en enajenación mental el imputado, se hubiere formalizado la investigación o se hubiere deducido acusación en su contra y el fiscal estima que corresponde adoptar una medida de seguridad. En tal caso, deberá presentar un requerimiento solicitando su aplicación en los términos señalados en el párrafo $2^{\circ}$ del Título VII del Libro IV CPP. La diferente regulación del art. 465 con la del art. 252 letra c) CPP plantea ciertas dudas, como también el diferente tratamiento procesal al caso del enajenado mental peligroso que comete el delito en tal estado respecto de aquel cuya enfermedad sobreviene con posterioridad al hecho imputado.

Si se observa la redacción de la causal de sobreseimiento temporal contenida en la letra c) del art. 252 CPP pareciera concluirse: a) que el sobreseimiento temporal siempre debiera decretarse en el caso de enajenación mental sobreviniente, y b) que la causal se configura si el imputado cae en enajenación mental "después de cometido el delito" y no "después de iniciado el procedimiento", como señala el art. 465 CPP. Una interpretación razonable

través de la eliminación de peligros. Se custodia al autor, se lo cura o se lo educa siempre que no pueda prescindirse de toda reacción, cuando quepa entender al hecho como desgracia ocasional (Jakobs, G., Derecho Penal, P.G. (Fundamentos y teoría de la imputación), $2^{a}$ ed., corregida, trad. Joaquín Cuello Contreras y José Luis Serrano, Marcial Pons, Madrid, 1997, pp. 37 y ss., pp. 593 y ss., sobre el concepto de igualdad como elemento constitutivo del concepto de imputabilidad, vid. 598 y ss.) .

${ }^{64}$ Cfr. también arts. 250 letra c) y 252 letra c) CPP. 
CEJ - El tratamiento del inimputable en el derecho procesal penal chileno

de ambos preceptos sería aquella que entendiera que prevalece el art. 465 CPP, en el primer caso, y el art. 252 letra c) CPP, en el segundo.

En efecto, la posibilidad de decretar un sobreseimiento definitivo en caso de enfermedad mental incurable es plenamente coherente con el fundamento de la institución: quien nunca podrá defenderse materialmente y ejercer en plenitud sus derechos en el proceso penal debe ser sobreseído definitivamente y no sólo temporalmente. Por otro lado, pensamos que para la aplicación de estas normas es suficiente que el imputado caiga en enajenación mental después de cometido el hecho, se haya o no iniciado el correspondiente procedimiento penal, pues el fundamento siempre es el mismo: el sujeto carecerá siempre de capacidad para defenderse materialmente de la imputación jurídico-penal. En este sentido resulta más acertada la regulación del art. 252 letra c) del CPP, que se refiere al imputado que cae en enajenación mental "después de cometido el delito". Otra interpretación dejaría fuera de esta regulación a quien devino enajenado mental después de cometido el hecho pero antes de iniciarse la persecución penal en su contra. Evidentemente, para que se dicte sobreseimiento temporal o definitivo, o se aplique alguna medida de seguridad, se requiere que haya comenzado el procedimiento pero como es fácil advertir, ello no es requisito indispensable para la determinación del estatuto regulativo aplicable al enajenado mental.

Por otro lado, el inciso final del art. 465 CPP pareciera dar a entender que deben haberse realizado ciertas actuaciones procesales por parte del ministerio público antes de que el imputado caiga en enajenación mental para poder solicitar la aplicación de una medida de seguridad, cuando concurran sus presupuestos, conforme al procedimiento establecido en el párrafo $2^{\circ}$ del Título VII del CPP. Como es evidente, ello no puede plantearse respecto del imputado que hubiere cometido el delito estando en situación de enajenación mental. No vemos la razón de la restricción procesal en el primer caso. Si el presupuesto de aplicación de la medida de seguridad es la posibilidad de realización de hechos futuros peligrosos que surge de la existencia de una enfermedad mental en el sujeto no se advierte por qué la solicitud de su imposición deba subordinarse a un acaso o al azar, esto es, a la circunstancia que la enajenación mental sobrevenga después de realizados ciertos actos procesales del ministerio público. En nuestra opinión, cualquiera sea el momento procesal en que sobrevenga la enfermedad mental del imputado podrá solicitarse la aplicación de una medida de seguridad, si se dan sus presupuestos.

Si el estado de enajenación mental del imputado es transitorio, posibilidad que la psiquiatría forense ha controvertido y puesto en tela de juicio a propósito de los "intervalos lúcidos" a que se refiere el artículo $10 \mathrm{~N}^{\mathrm{o}} 1$ del 
REJ - Revista de Estudios de la Justicia - No 10 - Año 2008

Código Penal ${ }^{65}$, el procedimiento penal deberá ser reiniciado a fin de que el imputado sea enjuiciado conforme a las reglas generales (art. $254 \mathrm{CPP}$ ).

${ }^{65}$ Cfr. Etcheberry, A., Derecho Penal, P.G. Tomo I, cit., p. 282-283, quien señala que sólo puede haber una remisión aparente del trastorno mental, pues la enfermedad sigue latente e influyendo en los procesos psíquicos, aunque reconoce que es un tema controvertido en la disciplina psiquiátrica. 